\title{
A Spotlight of Co-creation and Inclusiveness of Public Open Spaces
}

\author{
Ina Šuklje Erjavec ${ }^{1(\bowtie)}$ and Tatiana Ruchinskaya ${ }^{2}$ \\ ${ }^{1}$ Urban Planning Institute of the Republic of Slovenia, Ljubljana, Slovenia \\ inas@uirs.si \\ 2 JT Environmental Consultants Ltd., TVR Design, Cambridge, UK \\ tvr281@hotmailco.uk
}

\begin{abstract}
This chapter focuses on co-creation as the way to engage different stakeholders with everyday urban environments based on equality, diversity and social cohesion. It presents the relationship of co-creation and inclusiveness of public open spaces together with different aspects of co-creation related to issues of publicness and space. It discusses why and how co-creation must take into consideration the characteristics of the comprehensive spatial development processes. It suggests that co-creation is a wider concept than co-design and is a multistage process that contributes to inclusive public spaces, providing measures for social sustainability of place. This chapter argues that digital tools may help to overcome challenges of co-creation and provide an opinion on the contribution of digital technologies to the co-creation process by engaging people in the design, use and management of public spaces, providing new resources for interaction and users' empowerment. For that it presents an overview of the possible contribution of digital technologies to support inclusiveness of the co-creation processes that is structured by typologies of digital tools and their possible interlinking with the steps of the co-creation process. To improve the understanding of such possibilities it critically addresses strengths and weaknesses of using digital tools for co-creation and inclusiveness and provides recommendations for their further development.
\end{abstract}

Keywords: Co-creation $\cdot$ Inclusiveness $\cdot$ Digital tool

\section{Introduction}

Public spaces are defined by UNESCO (2017) as "social space that is generally open and accessible to people". Public spaces are regarded as democratic if they are constituted with forms of participatory democracy, meaning a "variety of processes providing people's involvement in decision-making and the rights to participate in society" (Maduz 2010; Omtzigt 2009; Parkinson 2012).

Social inclusion contributes to provision of participatory democracy of the public places in design, use and their management and neglecting it can have detrimental consequences for a success of the public places (IGOP 2017). However even in the democratic societies the exclusion can be obvious, and in many cases, has to be 
addressed between the lines. Social inclusion defined as "the process of improving the terms of participation in society, particularly for people who are disadvantaged, through enhancing opportunities, access to resources, voice and respect for rights" (UN 2016).

Active participation in design, use and management of public spaces can be facilitated by the following methods:

- Public participation, defined as a "two-way communication and collaborative problem solving with the goal of achieving better and more acceptable decisions" (Atkinson et al. 2003; Creighton \& Creighton 2008).

- Community engagement is a dimension of public participation and "a process of inclusive participation which supports mutual respect of values, strategies, and actions for authentic partnership of people affiliated with or self-identified by geographic proximity, special interest or similar situations to address issues affecting the well-being of the community" (Jones and Wells 2007).

- Co-creation process as a special type of collaboration, where people are working or acting jointly with others to create something that is not known in advance. "Cocreation is an act of collective creativity" (Sanders and Stappers 2008).

It is notable that the co-creation method is fundamentally different from public participation and citizen engagement. It increases opportunities for achieving social inclusion in public places because it recognises the decision-making rights of people, produce a new public value, promote of community self-organisation and empowerment of the excluded. (Leading Cities 2014; Sanches and Frankel 2010). It has a potential for overcoming the limitations of time and geography and may allow a significant leap in the scale and influence of public involvement" (Leading Cities 2014).

Whereas public open spaces involve both spatial as well as social structures, their characteristics are as much formed by the activities, attitudes and perceptions of people as they are by physical setting, features and elements. Moreover, the presence or absence of people defines the character and spirit of public place, influences its attractiveness, and forms its visual appearance, extending the concept of co-creation beyond planning and design activities to the area of implementation, use and management of place as well. Being public, such places should also cater for diversity of population, allowing people of all ages, sizes, abilities and disabilities to use and enjoy public places. Providing facilities for one group of users should result in solutions that addresses the needs of many other groups. Aspects of equality and inclusion within processes of co-creation are challenging.

From here the co-creation process in design, use and management of public open spaces is investigated further as an advanced process of participative democracy and a necessary condition of a more inclusive society. Thus, inclusiveness is considered to underpin the philosophy of co-creation processes and is implemented through inclusive indicators, including collaboration of uses, empowerment of community, interactivity, connectivity, equality, accessibility, efficiency, convenience and flexibility (Design Council 2017; CABE 2006). However, in reality it is difficult to accomplish all of them. Thus, it is accepted that inclusiveness in co-creation process can be achieved on an offset basis, where the achievement of several inclusive indicators compensates for, or offsets, others. 
The chapter studies co-creation processes in public spaces in its wider context and investigates advantages of using digital tools to support co-creation activities and facilitate inclusiveness of public places.

\section{Co-creation Within the Context of Public Open Space}

Initially, the term co-creation has been used as an innovation management term and a form of economic strategy. It was defined by Prahalad and Ramaswamy as part of a product development and business strategy as "the joint creation of value by the company and the customer; allowing the customer to co-construct the service experience to suit their context" (Prahalad and Ramaswamy 2004). Surprisingly, it is less common in 'creative' disciplines like architecture, urban planning and design. There collaborative approaches are defined as public participation, participatory design, cooperative design, co-design, hands-on urbanism and similar. However, such concepts are not covering all the important and relevant aspects of the co-creation related to comprehensive spatial development but represent its individual parts and units of the wider context.

Co-creation for spatial development means a joint development, generation, production and creation of new proposals of "contextual and unique solutions" that are based on specific, local and personal knowledge and skills, potentials and opportunities as well as problems, and obstacles of the community and place. In the Co-Creating Cities publication prepared by Leading Cities in 2014, the co-creative process is defined by nine key characteristics. These are: "systemic, innovative and productive, collaborative, diverse, hierarchy-flattening, bi-or multi-directional, repeated and intense, mutually beneficial and trusted and transparent" (Leading Cities 2014).

Co-creative techniques give communities and individuals more direct involvement in defining their needs and priorities, collaboratively finding solutions, influencing decisions and achieving better outcomes. This process requires a transparency of a cocreation process as well as good, supporting tools and methodologies for information and ideas flow among stakeholders, their interaction and mutual development of knowledge and skills. That produces significant challenges in terms of the time and costs required to effectively engage stakeholder groups and to create accessible representations that help citizens in their participation and engagement. The requirement to process a huge amount and complexity of information could create barriers for a successful co-creation process.

An even bigger challenge is to successfully address the aspect of "common benefits for the whole community," which is especially relevant in the context of public open space. To be "inclusive and collaborative" means to be a process accessible to all, involving and equally addressing different context-related stakeholders, from public authorities, experts, NGOs to entire publics, and foster cross-sectoral cooperation. Therefore, it should incorporate a variety of principles, methods and tools to encourage and support the participation and transforms stakeholders from "passive audiences" to "active players". Very important aspect for the long-term reliability and successfulness is 'credibility'. That means, that participants and all others concerned can trust and feel confident about the aims, issues and process development and see evidence that their 
views have been considered. This also means that all sources of information, creative process steps and decision-making elements are transparent and verifiable within the whole process.

To be "open and responsive" is not only sharing and deciding but also developing and doing things, which is flexible enough to respond and adapt to social and spatial context and change. And has no pre-defined optimum solutions or preferences. Such approach is neither top-down nor bottom-up but shares power between government, citizens and other stakeholders, and creates partnership for consensus.

Co-creation is also a co-learning process, in which stakeholders learn from one another and participants assist each other to develop better solutions and improve the quality of life and local environment of the whole community in the long-term. Creating new dimensions of collective creativity on each stage of co-creation from identification of the problem to implementation of results and managing outcomes, provide people an equal opportunity to engage in the decision making, where everyone can be creative and contribute to the place making. Integration of resources during cocreation improves the adaptability of co-creation process. The flexibility of the process achieved by integration of knowledge of different users and understanding that, what is being created can be changed by the community.

To effectively use all the potentials of the co-creation approach for the development of public open spaces, it is necessary to understand it in its broader sense. That means taking into consideration also aspects of spatial setting and social functioning of public open space. To achieve this, the concept of co-creating public open spaces must include all stages of the spatial development process and address all types of related collaboration activities. That is: involving end users (citizens) and other relevant stakeholders, sharing information and local knowledge, collaborating on data gathering, expressing opinions, needs, wishes and values, defining priorities visions and aims, decision making as well as the placemaking with different participatory planning and co-design activities, co-management.

When dealing with public spaces, the co-creation aspects of actual activities and creativity of users in real time and space, may be sometimes even more relevant for successful development of the place and its inclusiveness. Involving citizens into implementation and management of real public open space opens another dimension of co-creation, the dimension of actual 'doing'. It means co-producing, the physical, spatial solutions, interventions, values, identities, contents and messages thus coforming and co-developing spatial and social characteristics of place.

This wider understanding of possible acts of co-creation for public open space development is in line with the Four-D Model for Civic Engagement, defining four important categories of engagement: "Discover, Debate, Decide and Do" (Digital Engagement Cookbook 2017). By the scheme bellow (Fig. 1), we present the interrelation between co-creation approach and open space development. It demonstrates how co-creation extends to the "DO category", thus the co-creating activities of implementation, use and management of place. To better explain how the co-creation could be applied into the comprehensive spatial development process, it presents different relations to some more often used aspects and methodologies.

With suitable design of place and its elements (especially when using opportunities of new technologies) such co-creation of real places could be extended in time as its 
Co-creation within time line of open space development

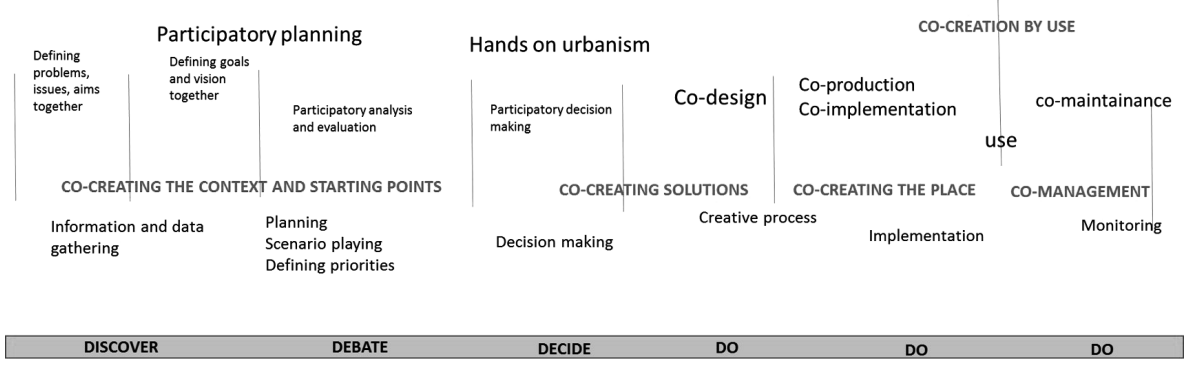

Fig. 1. Co-creation within the timeline of the public open space development

permanent adaptability and responsiveness to users' interventions and needs. Many new technologies such as touch screens, interactive surfaces and elements, smart furniture and other responsive environmental systems using sensors and actuators, embedded sound and video systems, microclimate control systems and similar, are offering a wide range of possibilities for users to temporarily or permanently change, adapt, personalise the place or respond to it by their activities and ways of use.

\section{Using Digital Tools for Co-creation and Inclusiveness}

The use of new technologies in our everyday life for work, education and leisure is becoming a reality as well as big challenge for urban development. Information and communications technologies (ICT) and digital literacy are increasingly necessary to engage in everyday social activities - to access public information, to bring together different kinds of knowledge, to facilitate communication and collaboration between a growing number of projects and initiatives, to communicate with social networks, to spread new skills and abilities, etc. Digital transition will not automatically provide us with inclusive society, but it can contribute to "building more equal, fairer and empowering society provided that there is a political will".

In the process of co-creation of public spaces, ICT can be a useful tool to overcome challenges and to achieve inclusiveness of public spaces, providing different types of assistance and contributing to equality and accessibility of co-creation process (Table 1). Digital tools are suitable for all age groups; they provide different forms of outreach to all, and an option of equal access to the internet and to important online resources.

The combination of offline and online tools is beneficial for changing the demographics of community engagement. Digital tools can assist in learning new skills and getting a new knowledge and sharing information. They can be especially supportive to particular groups of people (for example disabled users and young people) as may improve access and use of places for disabled people, encourage them to be socially active and increase opportunities that a place can offer to them. 
Table 1. Using digital tools for supporting different actions and activities of the co-creation process.

\begin{tabular}{|c|c|c|}
\hline $\begin{array}{l}\text { Co-creation } \\
\text { process actions }\end{array}$ & Co-creation activities & Examples of specific digital tools \\
\hline $\begin{array}{l}\text { PREPARATION } \\
\text { Co-creating the } \\
\text { context and starting } \\
\text { points }\end{array}$ & $\begin{array}{l}\text { Defining problems issues } \\
\text { and aims, Defining goals } \\
\text { and visions } \\
\text { Public engagement } \\
\text { Choosing priorities \& } \\
\text { Setting budgets }\end{array}$ & $\begin{array}{l}\text { Better Reykjavik, CitizenLab, } \\
\text { Engagement HQ, Front Porch Forum, } \\
\text { Hy.OpenInnovation, i-Neighbors, } \\
\text { MiMedellín (Colombia), NextDoor, } \\
\text { Nexthamburg, Our Common Place, } \\
\text { StickyRoom, Wheelmap (Germany); } \\
\text { WayCyberparks; } \\
\text { Budget Simulator, Citizen Budget, } \\
\text { CrowdGauge, Wejit }\end{array}$ \\
\hline \multirow[t]{4}{*}{$\begin{array}{l}\text { DISCOVER for } \\
\text { understanding } \\
\text { urban reality } \\
\text { Spatial and social } \\
\text { analysis of the local } \\
\text { context }\end{array}$} & $\begin{array}{l}\text { Information, engagement, } \\
\text { crowdsourcing }\end{array}$ & $\begin{array}{l}\text { Better Reykjavik, CitizenLab, } \\
\text { Engagement HQ, Front Porch Forum, } \\
\text { Hy.OpenInnovation, i-Neighbors, } \\
\text { MiMedellín (Colombia), NextDoor, } \\
\text { Nexthamburg, Our Common Place, } \\
\text { StickyRoom, Wheelmap (Germany); } \\
\text { WayCyberparks; }\end{array}$ \\
\hline & $\begin{array}{l}\text { Engage with location, } \\
\text { Community mapping, data } \\
\text { collection }\end{array}$ & $\begin{array}{l}\text { BlockPooling, Foursquare, Harvest } \\
\text { Digital Planning, Madame Mayor I have } \\
\text { an idea (France), Placecheck (UK), } \\
\text { Social Pinpoint, Sparq® }{ }^{\circledR} \text {, Textizen } \\
\text { Poll, YouCanPlan, Whrr }\end{array}$ \\
\hline & Storing information & Cloud, harKopen, Social Pinpoint \\
\hline & Making sense of data & $\begin{array}{l}\text { CivicInsight, Many Eyes, FixMyStreet, } \\
\text { VoiceYourView, Peckham Coal Line } \\
\text { and Kirkwood green Space (UK) }\end{array}$ \\
\hline \multirow{7}{*}{$\begin{array}{l}\text { DEBATE } \\
\text { evaluation, } \\
\text { refinement of ideas }\end{array}$} & Reporting & FixMyStreet, Public Stuff, SeeClickFix \\
\hline & Brainstorming & $\begin{array}{l}\text { Codigital, Ethel, e-deliberation, } \\
\text { Loomio, Neighborland, Open Planet } \\
\text { Ideas, Stickyworld }\end{array}$ \\
\hline & Sharing knowledge & $\begin{array}{l}\text { Community Almanac, Location-Aware } \\
\text { Multimedia Stories, Neighborhow }\end{array}$ \\
\hline & Annotating places & Placecheck app, Ushahidi \\
\hline & Visualization \& discussion & $\begin{array}{l}\text { Lapse, Many Eyes, Spatial Media, } \\
\text { StickyRoom }\end{array}$ \\
\hline & $\begin{array}{l}\text { Offline and online } \\
\text { experiences }\end{array}$ & Consultation Manager, Quirky \\
\hline & Offering rewards for ideas & Innocentive, OpenIdeo \\
\hline DECIDE & $\begin{array}{l}\text { Share ideas, joint decision- } \\
\text { making }\end{array}$ & $\begin{array}{l}\text { Civic Commons, Flemish Living Lab } \\
\text { Platform, harKopen, Innocentive, } \\
\text { Quirky, Loomio - Walk [Your City] } \\
\text { (USA), Madame Mayor I have an idea } \\
\text { (France), Many Eyes, M@ @or Labs, }\end{array}$ \\
\hline
\end{tabular}


Table 1. (continued)

\begin{tabular}{|c|c|c|}
\hline $\begin{array}{l}\text { Co-creation } \\
\text { process actions }\end{array}$ & Co-creation activities & Examples of specific digital tools \\
\hline & & $\begin{array}{l}\text { Minecraft (UN Programme), OpenIdeo, } \\
\text { Open Planet Ideas, Sparq® } 3 \text {, } \\
\text { Wheelmap (Germany) }\end{array}$ \\
\hline & Voting & Cityzen, Open IDEO, \\
\hline & $\begin{array}{l}\text { Raise awareness and lobby } \\
\text { governments }\end{array}$ & Websites Walk Your City (USA) \\
\hline & Budged voting & Citizen Budget \\
\hline \multirow[t]{5}{*}{$\begin{array}{l}\text { DO - design a } \\
\text { solution }\end{array}$} & All in one & $\begin{array}{l}\text { M@nor Labs, OpenIdeo, Open Planet } \\
\text { Ideas }\end{array}$ \\
\hline & Co-design & \\
\hline & $\begin{array}{l}\text { Modelling concepts and } \\
\text { virtual prototypes }\end{array}$ & $\begin{array}{l}\text { Connect to Life, Flux Space, Lapse, } \\
\text { Many Eyes }\end{array}$ \\
\hline & $\begin{array}{l}\text { Site specific media } \\
\text { experiences }\end{array}$ & Cityscape Digital, MetroQuest \\
\hline & $\begin{array}{l}\text { Play a game and plan for } \\
\text { your community }\end{array}$ & $\begin{array}{l}\text { Community PlanIt, CrowdGauge, Fold- } \\
\text { it, Foursquare, M@nor Labs, Minecraft }\end{array}$ \\
\hline $\begin{array}{l}\text { DO - delivery \& } \\
\text { implementation }\end{array}$ & $\begin{array}{l}\text { Execution of the project } \\
\text { Showcase of results } \\
\text { Physical co- } \\
\text { implementation - public } \\
\text { engagement }\end{array}$ & MetroQuest, Digital Planning \\
\hline DO - use & $\begin{array}{l}\text { Site specific (media) } \\
\text { experiences } \\
\text { Co-creation by use }\end{array}$ & $\begin{array}{l}\text { Digital installations, media screens, The } \\
\text { Intel Connect to Life Experience }\end{array}$ \\
\hline MAINTAIN & Public engagement & \\
\hline MONITOR & $\begin{array}{l}\text { Questionnaires } \\
\text { Direct data feedback from } \\
\text { users }\end{array}$ & $\begin{array}{l}\text { Ask Them PPF, All Our Ideas, Citizen } \\
\text { Space, Google forms, Granicus } \\
\text { SpeakUp, Wiki surveys }\end{array}$ \\
\hline
\end{tabular}

There is a big choice of digital tools available for the co-creation of public spaces. There are mobile applications, digital platforms, digital social networking websites, social media channels, blogs, site-specific media experiences, etc. These tools support either the whole process of co-creation of public spaces or its specific activities as presented in the overview table.

Examples of platforms that support the whole process of co-creation of public spaces include StickyWorld (StickyWorld 2017) and YouCanPlan (YouCanPlan 2017). There are also more general co-creation platforms, initiated by platform owners, or their partner organizations which could be used in any industry, for example OpenIDEO (OpenIDEO 2017) and Quirky (Quirky 2017), Idea Connection (Idea connection 2017), CitizenLab (CitizenLab 2017), Crowdbrite (Crowdbrite Solutions 2017) and 
EveryAware (EveryAware 2016). They can me modified to customer requirements by their software providers. Webbased Networks (for example, Living Labs (ENoLL 2017) provide offline and online opportunities to participate in co-creation processes, which makes the process more attractive and accessible to certain groups of users. Digital platforms, where community members can initiate projects, connect community members around a shared interest, collect contributions and compile these contributions to a solution (HitRecord, Quirky).

There are city-specific co-creation projects, which use their own digital platforms with a strong local identity aiming to empower local communities to take ownership of changes in cities and combining online with offline approaches. OrganiCity is an EUfunded project, for co-creative practices in Aarhus, London and Santander, challenging mobility, air quality and urban regeneration. Zo! City was launched in 2010 in southeast Amsterdam (Netherlands) by TransformCity. It is based on storytelling to make the platform easy to engage with (Transform City 2015). Co-creation platforms Medellín (Medellín 2017) and Better Reykjavik (Citizens Foundation 2017) allow citizens to play a key part in the transformation of the city. They are designed for citizen solutions to these city's urban challenges. The Nooks and Crannies co-creation project and platform focused on local improvements in Bristol (UK) for the redesign of a link bridge and access lane (Hands on Bristol 2014). These platforms are "fragmented and uncertain on the demand-side and lacking common standards in the supply-side" and are not well-connected to "rapidly growing data" (European Innovation Partnership 2016). A common framework of co-creation process in cities should be established, so it can be applied to the needs of particular cities or places.

Platforms that support the whole process of co-creation are able to provide a high level of transparency of the process, activities and outcomes of co-creation, which motivates users to get engaged with the project (Nambisan and Nambisan 2013). It is argued that digital tools are successful in facilitating inclusiveness of co-creation process in public spaces and that they are good for supporting inclusive indicators (Table 2).

Table 2. Advantages and disadvantages of using digital tools for inclusive co-creation of public spaces.

\begin{tabular}{l|l|l}
\hline $\begin{array}{l}\text { Indicators of } \\
\text { inclusion }\end{array}$ & $\begin{array}{l}\text { Advantages of using digital tools } \\
\text { for inclusive co-creation of public } \\
\text { spaces }\end{array}$ & $\begin{array}{l}\text { Disadvantages of using digital tools } \\
\text { for inclusive co-creation of public } \\
\text { spaces }\end{array}$ \\
\hline $\begin{array}{l}\text { Empowerment } \\
\text { of community }\end{array}$ & $\begin{array}{l}\text { Assisting in giving people } \\
\text { decision making powers, dialog } \\
\text { and control }\end{array}$ & $\begin{array}{l}\text { Requires a moderator, manager } \\
\text { and facilitator. } \\
\text { Can be dominated by articulate and } \\
\text { confident individuals if not } \\
\text { carefully facilitated }\end{array}$ \\
\hline
\end{tabular}


Table 2. (continued)

\begin{tabular}{|c|c|c|}
\hline $\begin{array}{l}\text { Indicators of } \\
\text { inclusion }\end{array}$ & $\begin{array}{l}\text { Advantages of using digital tools } \\
\text { for inclusive co-creation of public } \\
\text { spaces }\end{array}$ & $\begin{array}{l}\text { Disadvantages of using digital tools } \\
\text { for inclusive co-creation of public } \\
\text { spaces }\end{array}$ \\
\hline Collaboration & $\begin{array}{l}\text { - Providing logistics to co-creation } \\
\text { process, including } \\
\text { understanding, improvement, } \\
\text { and addressing urban issues } \\
\text { - Provide an ability to communicate } \\
\text { with social networks } \\
\text { - Changing the demographics of } \\
\text { co-creation process } \\
\text { - Targeting at excluded or 'hard to } \\
\text { reach groups' } \\
\text { - Developing a common vision and } \\
\text { assist to jointly create a product or } \\
\text { service } \\
\text { - Generating discussions } \\
\text { - Assisting in handling conflicts } \\
\text { - Building a sense of community } \\
\text { ownership } \\
\text { - Facilitating collaborating between } \\
\text { projects and initiatives } \\
\text { - Facilitating transparency of } \\
\text { decision-making processes } \\
\text { - Assisting in spreading of new } \\
\text { skills and knowledge }\end{array}$ & $\begin{array}{l}\text { - Requires a moderator, manager } \\
\text { and facilitator } \\
\text { - Workshops can be dominated by } \\
\text { articulate and confident individuals } \\
\text { if not carefully facilitated } \\
\text { - Difference in participant } \\
\text { confidence in their creative skills } \\
\text { - Cybersecurity, targeted filtering, } \\
\text { fake information, gender and racial } \\
\text { bias embedded into various } \\
\text { algorithms }\end{array}$ \\
\hline Efficiency & $\begin{array}{l}\text { - Cost \& Time Effective } \\
\text { - Robust data collection, its } \\
\text { analysis, categorization, } \\
\text { redistribution of information } \\
\text { - Provide different forms of } \\
\text { outreach to stakeholder groups } \\
\text { - Efficient way of identifying and } \\
\text { clarifying key issues } \\
\text { - Bring together different kinds of } \\
\text { knowledge } \\
\text { - Easy evaluation of a results of co- } \\
\text { creation }\end{array}$ & $\begin{array}{l}\text { - Requires financial sustainability } \\
\text { - Cybersecurity, targeted filtering, } \\
\text { fake information }\end{array}$ \\
\hline Interactivity & $\begin{array}{l}\text { - Interactive and engaging } \\
\text { - Creating debates and exchange of } \\
\text { views } \\
\text { - Assisting in decipher of urban } \\
\text { information } \\
\text { - Enabling participants to express } \\
\text { their creativity }\end{array}$ & $\begin{array}{l}\text { - Needs to be publicized to generate } \\
\text { interest } \\
\text { - Excludes those without access to } \\
\text { the internet } \\
\text { - Difference in participant's } \\
\text { confidence in their creative skills } \\
\text { - Difficult to interpret participant's } \\
\text { ideas }\end{array}$ \\
\hline
\end{tabular}


Table 2. (continued)

\begin{tabular}{|c|c|c|}
\hline $\begin{array}{l}\text { Indicators of } \\
\text { inclusion }\end{array}$ & $\begin{array}{l}\text { Advantages of using digital tools } \\
\text { for inclusive co-creation of public } \\
\text { spaces }\end{array}$ & $\begin{array}{l}\text { Disadvantages of using digital tools } \\
\text { for inclusive co-creation of public } \\
\text { spaces }\end{array}$ \\
\hline & $\begin{array}{l}\text { - Facilitating transparency of } \\
\text { decision-making processes } \\
\text { - Adding variety to consultation } \\
\text { - Engaging people who might not } \\
\text { otherwise get involved }\end{array}$ & $\begin{array}{l}\text { - Cybersecurity, targeted filtering, } \\
\text { fake information }\end{array}$ \\
\hline Connectivity & $\begin{array}{l}\text { - Reaching a larger number of } \\
\text { people } \\
\text { - Spreading of new skills and } \\
\text { knowledge }\end{array}$ & $\begin{array}{l}\text { - Excludes those without access to } \\
\text { the internet }\end{array}$ \\
\hline Equality & $\begin{array}{l}\text { - Suitable for all age groups } \\
\text { - Providing different forms of } \\
\text { outreach to stakeholder groups } \\
\text { - Attractive to particular groups of } \\
\text { people } \\
\text { - Respecting people privacy } \\
\text { - Providing an option of equal } \\
\text { access to internet and important } \\
\text { online resources } \\
\text { - Spreading of new skills and } \\
\text { knowledge }\end{array}$ & $\begin{array}{l}\text { - Needs to be publicized to generate } \\
\text { interest } \\
\text { - Excludes those without access to } \\
\text { the internet } \\
\text { - Difficult to be sure that all } \\
\text { stakeholders or interests are } \\
\text { represented } \\
\text { - Some people may feel intimidated } \\
\text { - Cybersecurity, gender and racial } \\
\text { bias embedded into various } \\
\text { algorithms }\end{array}$ \\
\hline Accessibility & $\begin{array}{l}\text { - Accessible to people of all } \\
\text { abilities and backgrounds }\end{array}$ & $\begin{array}{l}\text { - Excludes those without access to } \\
\text { the internet }\end{array}$ \\
\hline Convenience & $\begin{array}{l}\text { - Addressing the objectives of co- } \\
\text { creation } \\
\text { - Choosing a convenient time and } \\
\text { place to participate } \\
\text { - Providing different forms of } \\
\text { outreach to stakeholder groups } \\
\text { - Overcoming distances, } \\
\text { - Moving through different layers } \\
\text { of spaces and time } \\
\text { - Creating boundaries and memory } \\
\text { - Creating read/write publishing } \\
\text { - Rpace }\end{array}$ & - Cybersecurity \\
\hline Flexibility & $\begin{array}{l}\text { - Providing different forms of } \\
\text { participation, connected to } \\
\text { understanding, improvement, } \\
\text { and subversion of urban issues } \\
\text { - Providing different forms of } \\
\text { outreach to different stakeholders } \\
\text { - Designed for a specific purpose. } \\
\text { - Choosing the most appropriate } \\
\text { type and form of outreach }\end{array}$ & - Cybersecurity \\
\hline
\end{tabular}


Digital tools can be used to generate citizen empowerment by improving collaboration, dialog and control in co-creation process of public spaces and giving people decision making powers. At the same time, portable technologies have an ability to personalize public spaces through users' maps, photos, experiences, etc., which give people a feeling of personal belonging (Iaconesi and Persico 2013).

Digital tools can improve the efficiency of collaboration in co-creation process of public spaces. The support of digital tools in tasks that requires, scale, speed, interactivity, connectivity "is not a luxury, but a non-negotiable necessity" (Bhalla 2016). It makes the logistics simpler and brings a community into contact with the co- creation process. It provides more robust data collection and its analysis, categorization, redistribution of information and acquiring new skills. Online dialogues are less costly, quicker and easier to arrange, and can involve a much larger number of stakeholders and citizens (Viegas et al. 2007; Sinclair et al. 2007).

Digital tools can be applied in layers to address different objectives of co-creation in public spaces making the process more flexible and user orientated. For example, they can contribute to generation of ideas, which involves understanding, discussion of urban issues, refinement of features and co- creation (Janner-Klausner 2017; Bhalla 2016).

Technology-enabled approaches, providing different types of assistance, may contribute to equality and accessibility of co-creation process. They are suitable for all age groups; provide different forms of outreach to all, and an option of equal access to internet and to important online resources. Digital tools can be more attractive to particular groups of people (for example disabled users and young people) as they improve access and use of places for disabled people, encourage them to be socially active and increase opportunities that a place can offer to the users. They provide references to culture, heritage and public art in a digital format, which is very attractive to young people. Digital tools can assist in learning new skills and acquiring new knowledge. The combination of offline and online tools is beneficial for changing the demographics of community engagement.

Digital tools may encourage interactivity in co-creation of public spaces. They can support public debates, exchanging views, interpreting urban information, and enabling participants to express their creativity. They provide a variety of entry points to consultation and transparency around decision-making processes. The application of digital tools can provide a convenient and flexible way to co-create public spaces. These tools allow people to choose the appropriate methodology for the project that can be designed for a specific purpose at convenient time and place for participation, while at the same time respecting people's privacy. They assist in overcoming distance, to move through different layers of spaces and time. They can create boundaries, memories and read/write publishing spaces.

There are challenges of management, both personal and digital, in using IT tools for the co-creation of public places. Online co-creation processes require an experienced moderator as well as a manager and a facilitator. There are differences in participant confidence which should be considered when engaging different stakeholders in cocreation processes. Cybersecurity, targeted filtering, fake information, gender and racial bias embedded into various digital algorithms are challenges that should be addressed. Exclusion from communications and lack of ICT access, defined as service exclusion and considered as a dimension of social exclusion, are also known under the label 
'digital divide' and should be resolved at the government level (Sinclair et al. 2007). There is evidence that lack of access to ICT can foster disadvantages "in a direct way, relating to access to services and opportunities or indirect way, relating to local relationships and social capital" (Servon and Nelson 2001; Pantazis et al. 2006). Unaffordable costs, lack of awareness and trust to go online, luck of digital skills and communications literacy can lead to self-exclusion (GOV. UK 2014). These individuals are unable to participate in normal social life are "condition of "partial citizenship" (Sinclair et al. 2007).

\section{Discussion and Conclusions}

The co-creation of public open space is a way to engage different stakeholders with the everyday urban environment, based on equality, diversity and social cohesion. To appropriately address all the complexities of public space development, it should be considered a multi staged process, involving all phases of spatial development. That means addressing all types of related collaboration activities, including citizen engagement, sharing and interpreting information, co-learning, collaborating, expressing opinions, defining priorities, refining ideas, making decisions, creating common values, implementing solutions, monitoring, etc. In this way, positive outcomes of co-creation in public spaces exceed features of the final product, a spatial solution. It has a very strong potential to enrich the community life by creating interaction between the community members, to develop a local sense of place through active engagement with it, as well reducing vandalism and urban alienation.

However, it is difficult to involve diverse groups of people (e.g. academics, business people, non-profits, public servants, citizens) with different expectations regarding pace, style of work and timelines. The difference between experts and the general citizens, or between scholarly knowledge and informal knowledge, can also create conflicts and boundaries between stakeholders and undermine the legitimacy of the process. Any inequities that exist between groups of people involved should be balanced and effectively mitigated. Inclusive strategies for engaging hard-to-reach stakeholders, continuing dialogue, establishing partnerships and carrying out collaborative work should be introduced, while involving users in the process through workshops, user generated content, data collection, prototyping, or other activities, in order to get them engaged around the urban problem and suggest a solution.

This chapter argues that digital tools can be very useful to overcome different challenges of co-creation. They may provide different types of assistance for all age groups, contribute to equality and accessibility of co-creation process, enable learning new skills and promote healthier lifestyles. The overview of available digital tools proves there is a wide choice available for co-creation of public spaces, supporting either the whole process or its specific activities.

Many examples collected during the Cyberparks Project indicate that digital tools can contribute to a better understanding of public places, social networking, collaboration and community involvement (Cyberparks Project 2016). Introducing a digital layer to the existing public space for co-creation in real time and place may further improve an inclusive dimension of public place in physical and digital terms. 
'Decoding', 'debugging', and 'hacking' in public space are forms of participation, connected to understanding, improvement, and subversion of urban issues, which follows the main objectives of co-creation (Dork and Monteyne 2011). They assign roles to citizens and propose a range of activities to change the perception and reality of urban relations. Decoding involves publishing of data and spatial knowledge and its interpretation. The digital tools that can help to "decipher urban code" and "make sense of urban information streams", focusing on specific aspects of urban life, and making the issues more accessible, interactive and visual. By filing 'bug reports', citizens can report on urban issues by web-based forms. 'Hacking' public place is another way to reach the public by creating prototypes of change and spreading them like computer viruses.

Surprisingly, the wide range of opportunities of the use of ICT is still poorly recognized and discussed among urban planners and designers (Houghton et al. 2014). There are many specific challenges related to the planning processes from the both perspectives, use of ICT and co-creation. To effectively use the co-creation approach for planning and design of public open spaces it is important to closely relate and adjust all different aspects as well as different types of ICT tools to the particular stages of the spatial development timeline. New projects, as for example C3Places (C3Places 2018), are turning the focus also on planning and development aspects of quality of place, exploring how different potentials of ICT could be better understood and integrated into the POS development practice.

Finally, it is important to point out, that digital tools may be used also as a part of the design of place and its elements to attract co-creation and enable permanent adaptability and responsiveness of public open space. Many new technologies such as touch screens, interactive surfaces and elements, smart furniture and other responsive environmental systems using sensors and actuators, embedded sound and video systems, microclimate control systems and similar, are offering a wide range of possibilities for users to temporarily or permanently change, adapt, personalize the place or respond to it by their activities and ways of use.

\section{References}

Atkinson, T., Cantillon, B., Marlier, E., Nolan, B.: Social Indicators: The EU and Social Inclusion. Oxford University Press, Oxford (2003). https://doi.org/10.1093/0199253498.001.0001

Bhalla, G.: Collaboration and co-creation: the road to creating value. Mark. J., 25 May 2016. http://www.marketingjournal.org/collaboration-and-co-creation-the-road-to-creating-value/

CABE. Principles of inclusive design (2006). http://www.cabe.org.uk/files/the-principles-ofinclusive-design.pdf

CITIZEN BUDGET. Features (2017). http://www.citizenbudget.com/

Citizens Foundation. Better Reykjavík - Connects citizens to city hall (2017). http://www. citizens.is/portfolio/better-reykjavik-connects-citizens-and-administration-all-year-round/, auge. CrowdGauge (2017). http://crowdgauge.org/

CitizenLab. Co-create our city (2017). https://www.citizenlab.co/product

Consultation Manager. Top 5 Online Engagement Tools, 17 September 2016. https://consulta tionmanager.com/top5-online-engagement-tools/

Creighton \& Creighton, Inc. What is Public Participation? (2008). http://www.creightonandcreig hton.com 
Crowdbrite Solutions. Projects (2017). http://www.crowdbrite.net/

Design Council. Inclusive Environments (2017). http://www.designcouncil.org.uk/what-we-do/ inclusive-environments

C3Places Using ICT for co-creation of inclusive public places, JPI Urban Europe, 2017-2020. https://c3places.eu/

Cyberparks Fostering knowledge about the relationship between Information and Communication Technologies and Public Spaces supported by strategies to improve their use and attractiveness, COST Action TU 1306, 2015-2018. http://cyberparks-project.eu/

Digital Engagement Cookbook. Digital Engagement Cookbook, Methods Directory (2017). http://engagementdb.org

Dork, M., Monteyne, D.: Urban Co-Creation: Envisioning New Digital Tools for Activism and Experimentation in the City (2011). http://mariandoerk.de/urbancocreation/hpc2011.pdf

ENoLL. Living Labs (2017). http://www.openlivinglabs.eu/node/1429

European Innovation Partnership on smart cities and communities (EIP). Towards Open Urban Platforms for Smart Cities and Communities (2016). https://eu-smartcities.eu/sites/all/files/ MemorandumofUnderstandingonUrbanPlatforms.pdf

EveryAware. EveryAware Whitepaper, Enhancing Environmental Awareness through Social Information Technologies, November 2016. http://www.everyaware.eu/wp-content/uploads/ 2011/04/EveryAware.pdf

GOV.UK. Government Digital Inclusion Strategy, December 2014. https://www.gov.uk/ government/publications/government-digital-inclusion-strategy/government-digitalinclusion-strategy

Hands on Bristol. Nooks and Crannies (2014). http://www.hands-on-bristol.co.uk/new-page-1/

Houghton, K., Miller, E., Foth, M.: Integrating ICT into the planning process: impacts, opportunities and challenges. Aust. Planner 51(1), 24-33 (2014). https://doi.org/10.1080/ 07293682.2013 .770771

Iaconesi, S., Persico, O.: The co- creation of the city. Re-programming cities using real-time user generated content (2013). http://www.academia.edu/3013140/The_Co-Creation_of_the_City

Idea connection (2017). https://www.ideaconnection.com/open-innovation-services.html

IGOP. Social Inclusion and Participatory Democracy (2017). https://www.uclg-cisdp.org/en/ observatory/reports/social-inclusion-and-participatory-democracy-conceptual-discussionlocal-action

Janner-Klausner, D.: Using online tools for community engagement and consultation (2017). http://www.commonplace.is/blog/using-online-tools-for-community-engagement-and-consult ation

Jones, L., Wells, K.: Strategies for academic and clinician engagement in communityparticipatory partnered research. JAMA 297, 407-410 (2007)

Leading Cities. Co-Creating Cities: Defining Co-Creation as a Means of Citizen Engagement, March 2014. http://leadingcities2014.files.wordpress.com/2014/02/co-creation-formatteddraft-6.pdf

Maduz, L.: Direct democracy. Living Reviews in Democracy, vol. 2, University of Zurich (2010). https://www.lrd.ethz.ch/index.php/lrd/article/viewArticle/lrd-2010-1/22

Medellín. ¡Perticipa Y Haz Parte de la Transformasion! (2017). http://www.mimedellin.org/

Nambisan, S., Nambisan, P.: Engaging Citizens in Co-Creation in Public Services: Lessons Learned and Best Practices. IBM Center for The Business of Government (2013). http://www. businessofgovernment.org/sites/default/files/Engaging Citizens in Co-Creation in Public Service.pdf

Omtzigt, D.J.: Survey on Social inclusion: Theory and Policy. Oxford University, Oxford Institute for Global Economic Development, January 2009. http://ec.europa.eu/regional_ policy/archive/policy/future/pdf/1_omtzigt_final_formatted.pdf

OpenIDEO. Active challenges (2017). https://challenges.openideo.com 
Pantazis, C., Gordon, D., Levitas, R.: Poverty and Social Exclusion in Britain. The Policy Press, Bristol (2006)

Parkinson, J.: Democracy and Public Place. Oxford University Press, Oxford (2012). https:// chisineu.files.wordpress.com/2012/08/democracy-public-spaces.pdf

Prahalad, C.K., Ramaswamy, V.: Co-creation experiences: the next practice in value creation J. Interact. Mark. 18(3) (2004). https://deepblue.lib.umich.edu/bitstream/handle/2027.42/ 35225/20015_ftp.pdf

Quirky. Start Inventing (2017). https://www.quirky.com/

Sanches, M.G., Frankel, L.: Co-design in public spaces: an interdisciplinary approach to street furniture development (2010). http://www.drs2010.umontreal.ca/data/PDF/105.pdf

Sanders, E.B.N., Stappers, P.J.: Co-creation and the new landscapes of design. CoDesign 4(1), 518 (2008). https://doi.org/10.1080/15710880701875068

Servon, L.J., Nelson, M.K.: Community technology centres and the urban technology gap. Int. J. Urban Reg. Res. 25(2), 419-426 (2001)

Sinclair, S., Bramley, G., Dobbie, L., Morag, G.: Social Inclusion and communication. Review of Literature, November 2007. http://www.communicationsconsumerpanel.org.uk/downloads/ Research/LowIncomeConsumers_Research/Socialinclusionandcommunications/ Socialinclusionandcommunications.pdf

StickyWorld. Ideas Matter (2017). http://info.stickyworld.com/

Transform City. TransformCity ${ }^{\circledR}$ is the most integral and actionable urban transformation platform (2015). http://www.transformcity.com/

UN. Identifying social inclusion and exclusion (2016). http://www.un.org/esa/socdev/rwss/2016/ chapter1.pdf

Viegas, F.B., Wattenberg, M., van Ham, F., Kriss, J., McKeon, M.: Many eyes: a site for visualization at internet scale. TVCG: Trans. Vis. Comput. Graph. 13(6), 1121-1128 (2007)

UNESCO: Inclusion Through Access to Public Space Social and Human Sciences (2017). http:// www.unesco.org/new/en/social-and-human-sciences/themes/urban-development/migrantsinclusion-in-cities/good-practices/inclusion-through-access-to-public-space/

YouCanPlan. YouCanPlan (2017). http://www.participatedb.com/tools/193

Open Access This chapter is licensed under the terms of the Creative Commons Attribution 4.0 International License (http://creativecommons.org/licenses/by/4.0/), which permits use, sharing, adaptation, distribution and reproduction in any medium or format, as long as you give appropriate credit to the original author(s) and the source, provide a link to the Creative Commons license and indicate if changes were made.

The images or other third party material in this chapter are included in the chapter's Creative Commons license, unless indicated otherwise in a credit line to the material. If material is not included in the chapter's Creative Commons license and your intended use is not permitted by statutory regulation or exceeds the permitted use, you will need to obtain permission directly from the copyright holder.

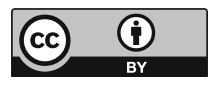

